\title{
Theileria, Babesia, AND ANaplasma deteCted by PCR In RUMinant heRdS at Bié Province, Angola
}

\author{
KUBELOVÁ M.*, MAZANCOVÁ J.** \& ŠIROKÝ P.*****
}

\section{Summary:}

Distribution of Anaplasma spp., Babesia spp., Theileria spp., and Ehrlichia ruminantium, was for the first time studied in Bié Province, central Angola. We examined 76 blood samples of cattle originated from seven farms, and 13 blood samples of goats from two farms employing molecular genetic tools (PCR). Most prevalent was $A$. ovis-infection in goats $(100 \%)$ and $A$. marginaleinfection in cattle (38\% of examined animals, and six out of seven farms). B. bigemina-infection was detected in only one specimen at Andulo, whereas $B$. bovis was not detected in Bié. We did not detected T. parva, the causative agent of serious diseases in cattle; nevertheless, infection by $T$. velifera was quite frequent $(14 \%$ of examined animals, and five out of seven farms). Causative agent of heartwater disease $-E$. ruminantium, was not detected. Taking into account short-term perspective of PCR methods in monitoring of epidemiological status in herds, the number of infected animals and distribution of detected pathogens should not be ignored.

KEY WORDS: tick-borne disease, epidemiology, prevention, diagnostics, blood parasite, Africa.

\section{INTRODUCTION}

T he tick-borne diseases are still closely related to huge economic losses particularly in developing countries (Uilenberg, 1995). Babesiosis (Tick fever), theilerioses (East Coast fever, January disease, and Corridor disease), ehrlichiosis (Heartwater disease), and anaplasmosis belong to the most important tick-transmitted diseases affecting cattle farming in sub-Saharan Africa (i.a. Gachohi et al., 2010; Makala et al., 2003; Okuthe \& Buyu, 2006). Worldwide distributed bovine babesiosis is caused by infection with intraerythrocytic parasites Babesia bovis and Babesia bigemina transmitted by Rhipicephalus

\footnotetext{
* Department of Biology and Wildlife Diseases, Faculty of Veterinary Hygiene and Ecology, University of Veterinary and Pharmaceutical Sciences Brno, Palackého 1-3, 61242 Brno, Czech Republic.

** Department of Sustainable Technologies, Institute of Tropics and Subtropics, Czech University of Life Sciences Prague, Kamýcká 129, 16521 Praha 6, Czech Republic.

**** CEITEC-Central European Institute of Technology, University of Veterinary and Pharmaceutical Sciences Brno, Palackého 1-3, 612 42 Brno, Czech Republic.

Correspondence: Pavel Široký.

Tel.: +420 541562635 - Fax: +420 541562631

E-mail: sirokyp@vfu.cz
}

Résumé : THEILERIA, BABESIA, ET ANAPLASMA DETECTÉs PAR PCR DANS DES TROUPEAUX DE RUMINANTS DE LA PROVINCE DE BIÉ EN ANGOLA La distribution d'Anaplasma spp., Babesia spp., Theileria spp. et Ehrlichia ruminantium a été pour la première fois étudiée dans la province de Bié, au centre de l'Angola. Nous avons examiné par PCR 76 échantillons de sang de bétail provenant de sept fermes et 13 échantillons de sang de chèvres de deux fermes. L'infection par A. ovis a été observée chez $100 \%$ des chèvres, celle par A. marginale chez $38 \%$ des animaux du bétail de six fermes sur sept, celle par B. bigemina chez seulement un spécimen à Andulo, tandis que B. bovis n'a pas été détecté dans cette province. Nous n'avons pas détecté T. parva, l'agent causal de maladies graves du bétail ; néanmoins, l'infection par T. velifera était assez fréquente (14\% $d$ 'animaux examinés de cinq fermes sur sept). E. ruminantium n'a pas été détecté. Le recours à la $P C R$ pour le suivi du statut épidémiologique des troupeaux (nombre d'animaux infectés et distribution des agents pathogènes) ne devrait pas être ignoré à court terme.

MOTS-CLÉS : maladies transmises par les tiques, épidémiologie, prévention, diagnostic, parasite du sang, Afrique.

spp. tick (Sonenshine, 1993). Competent tick vectors Rhipicephalus evertsi and Rhipicephalus (Boophilus) decoloratus were reported as a dominant tick species in livestock also in Angola (Gomes et al., 1994). The massive death associated with intravascular haemolysis should appear in endemic unstable areas where $B$. bovis is more pathogenic than $B$. bigemina. The most important diseases caused by Theileria spp. is undoubtedly connected with Theileria parva infection. Acute, frequently fatal East Coast fever is transmitted between cattle by Rhipicephalus appendiculatus tick, whereas Corridor disease causing almost $100 \%$ morbidity is transmitted from its asymptomatic carrier African buffalo (Syncerus caffer) to cattle also by Rhipicephalus zambeziensis and Rhipicephalus duttoni (Lawrence et al., 2004). Both, bovine anaplasmosis usually associated with Anaplasma marginale infection in cattle, and anaplasmosis of small ruminants caused by Anaplasma ovis are distributed worldwide with higher prevalence in tropical and subtropical areas (Bowles et al., 2000). An infection by this obligate intracellular parasite results in mild to severe anaemia and icterus without hemoglobinaemia and hemoglobinuria (Kocan et al., 2010). Febrile heartwater disease is endemic in sub-Saharan Africa and in the islands in the Carribean 
Sea (Provost \& Bezuidenhout, 1987). Ehrlichia ruminantium, its agent, causes serious lesions of nervous and circulatory system leading to reduction of cardiac and lung function (Van Amstel et al., 1987).

As a consequence of nearly 30 years lasting civil war, the basic information about current epidemiological status of livestock in Angola is lacking. After the war, domestic animals from different parts of Africa were taken to replace and re-form indigenous herds. We suppose that endemic stability in relation to tick-borne diseases is not understood to these days. In the frame of broader developmental project, we were allowed to perform a brief veterinary survey in Bié Province in Central Angola. Presented paper contributes to increase our knowledge on presence and distribution of four major tick-borne pathogens in this country.

\section{MATERIALS AND METHODS}

\section{BLOOD SAMPLING AND STUDIED AREA}

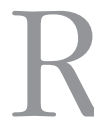
esearch was carried out in Bié Province in Central Angola during January and February 2009, the months representing there part of the rainy season (http://news.bbc.co.uk/weather/hi/ country_guides; http://www.angola.climatetemp.info/). Altogether 76 cattle blood samples were obtained by puncture of ventral coccygeal vein at seven selected farms operating by mixed farming system - namely in Andulo $(n=6)$, Cunhinga $(n=4)$, Kuito $(n=4)$, Kukema $(n=11)$, Kunje $(n=11)$, Lioema $(n=21)$, and Vila Graça $(n=19)$ (Fig. 1). All individuals originated from the south of the country (Huíla province) and belonged to local Ovambo breed. Thirteen (13) blood samples were collected from goats living in Catabola $(n=10)$ and Kuito $(n=3)$. All selected animals were adults without any symptom of disease. Small amount of collected full blood $(0.5 \mathrm{ml})$ was preserved by surplus of pure $96 \%$ ethanol and transported to laboratory.

\section{DNA EXTRACTION AND PCR AMPLIFICATION}

DNA was isolated from ethanol preserved blood using NucleoSpin Tissue kit (MACHEREY-NAGEL, Germany) following the manufacturer's protocol, and then stored at $-20{ }^{\circ} \mathrm{C}$ until further analysis. Polymerase chain reactions were conducted to amplify specific DNA fragments of Babesia/Theileria spp., Ehrlichia ruminantium, and Anaplasma marginale/ovis, following modified protocols published by da Silveira et al. (2011), Mahan et al. (1992), and de la Fuente et al. (2001), respectively. All reactions were performed in $25 \mu$ volume - PCR reaction mixture consisted of 12.5 ul Combi PPP Master Mix (Top-Bio s.r.o. Prague, Czech Republic), 10 pmol of each primer (Integrated DNA Technologies, Belgium), $8.5 \mu$ l of PCR water (Top-Bio s.r.o. Prague, Czech Republic), and $2 \mu \mathrm{l}$ of DNA template. In case of nested PCR (detection of Babesia/Theileria spp.), $1 \mu \mathrm{l}$ of PCR product from

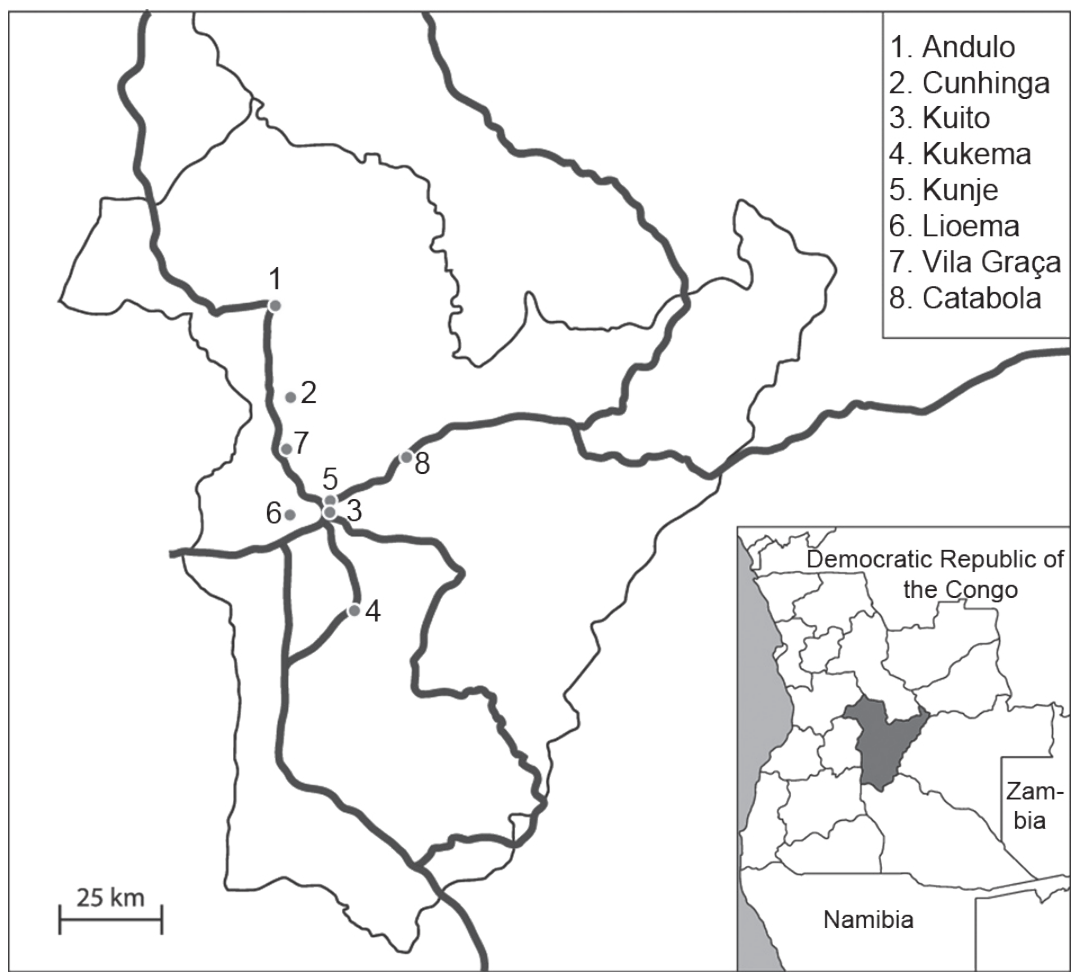

Fig. 1. - Distribution of sampling sites in Bié Province (dots).

Numbers at each locality correspond to those in the Table II. Position of Bié Province in the territory of Angola is evident on small inserted map at right down corner. 
the first round of amplification was used instead of DNA template.

The sequences of the primers and PCR conditions used in the study are presented in Table I. Initial denaturation step at $94^{\circ} \mathrm{C}$ lasted five, ten and two minutes for Babesia/Theileria spp., E. ruminantium, and A. marginale/ovis, respectively. Final extension step lasted eight minutes at $72^{\circ} \mathrm{C}$ for Babesia/Theileria spp., ten minutes at $72{ }^{\circ} \mathrm{C}$ for E. ruminantium, and seven minutes at $68{ }^{\circ} \mathrm{C}$ in case of $A$. marginale/ovis. All PCR products were subjected to $1.2 \%$ agarose gel with ethidium bromide and visualized under UV light.

\section{DNA SEQUENCING}

Representative part of positive PCR products were selected, purified after gel electrophoresis using Gel/ PCR DNA Fragments Extraction Kit (Geneaid Biotech Ltd., Taipei, Taiwan) and sequenced (Macrogen, Amsterdam, Netherlands). Similarity of the obtained sequences was compared with sequences available at GenBank database using BLAST (Basic Local Alignment Search Tool) algorithm (http://blast.ncbi.nlm. nih.gov/) and MEGA program (version 5.05, Tamura et al., 2011).

\section{RESULTS}

A 1113 goats' samples were positive only for the presence of partial sequence of msp4 gene coding Anaplasma marginale/ovis surface protein (Table II). Altogether nine out of 13 PCR products were sequenced and all of them revealed 98-100\% similarity to Chinese A. ovis isolates deposited in GenBank (HQ456347, HQ456348).

We detected gene segments of $A$. marginale, and Babesia/Theileria spp. in bovine blood samples (Table II). The msp4 gene of Anaplasma spp. was success-

\begin{tabular}{|c|c|c|c|c|c|c|c|c|}
\hline \multirow[b]{2}{*}{ Gene/target } & \multirow[b]{2}{*}{ Primers } & \multirow[b]{2}{*}{ Sequence 5 '- 3 ' } & \multicolumn{3}{|c|}{ PCR conditions $\left({ }^{\circ} \mathrm{C} / \mathrm{s}\right)$} & \multirow{2}{*}{$\begin{array}{c}\text { No. } \\
\text { of } \\
\text { cycles }\end{array}$} & \multirow{2}{*}{$\begin{array}{l}\text { Length } \\
\text { of PCR } \\
\text { product } \\
\text { (bp) }\end{array}$} & \multirow[b]{2}{*}{ References } \\
\hline & & & $\begin{array}{c}\text { Denatu- } \\
\text { ration }\end{array}$ & $\begin{array}{l}\text { Annea- } \\
\text { ling }\end{array}$ & $\begin{array}{c}\text { Exten- } \\
\text { sion }\end{array}$ & & & \\
\hline \multirow{4}{*}{$\begin{array}{l}18 \mathrm{~S} \text { rRNA gene/ } \\
\text { Babesia/ } \\
\text { Theileria sp. }\end{array}$} & RIB19 & CGGGATCCAACCTGGTTGATCCTGC & $92 / 60$ & $54 / 60$ & $72 / 120$ & 30 & 1,700 & \multirow{4}{*}{$\begin{array}{l}\text { da Silveira } \\
\text { et al. (2011) }\end{array}$} \\
\hline & RIB20 & CCGAATTCCTTGTTACGACTTCTC & & \multirow{3}{*}{$54 / 60$} & \multirow{3}{*}{$72 / 120$} & \multirow{3}{*}{30} & \multirow{3}{*}{420} & \\
\hline & BabRumF & ACCTCACCAGGTCCAGACAG & \multirow[t]{2}{*}{$92 / 60$} & & & & & \\
\hline & BabRumR & GTACAAAGGGCAGGGACGTA & & & & & & \\
\hline \multirow{2}{*}{$\begin{array}{l}\text { pCS2O gene } / E \text {. } \\
\text { ruminantium }\end{array}$} & AB 128 & ACTAGTAGAAATTGCACAATCTAT & \multirow[t]{2}{*}{$94 / 60$} & \multirow[t]{2}{*}{$55 / 60$} & \multirow[t]{2}{*}{$72 / 120$} & \multirow[t]{2}{*}{45} & \multirow[t]{2}{*}{279} & Mahan \\
\hline & AB 129 & TGATAACTIGGTGCGGGAAATCCTT & & & & & & et al. (1992) \\
\hline \multirow{2}{*}{$\begin{array}{l}\text { msp4 gene/A. } \\
\text { marginale/ovis }\end{array}$} & MSP 45 & GGGAGCTCCTATGAATTACAGAGAATTGTTTAC & \multirow[t]{2}{*}{$94 / 30$} & \multirow[t]{2}{*}{$60 / 30$} & \multirow[t]{2}{*}{$68 / 60$} & \multirow[t]{2}{*}{40} & \multirow[t]{2}{*}{851} & de la Fuente \\
\hline & MSP 43 & CCCCGGATCCTTAGCTGAACAGGAATCTTGC & & & & & & et al. (2001) \\
\hline
\end{tabular}

Table I. - PCR conditions and primers used in the study.

\begin{tabular}{|c|c|c|c|c|c|c|}
\hline & \multirow[b]{2}{*}{ Farm } & \multicolumn{5}{|c|}{ Number of positive/examined animals (prevalence \%) } \\
\hline & & Theileria sp. & Babesia sp. & $\begin{array}{c}\text { Ebrlichia } \\
\text { ruminantium }\end{array}$ & $\begin{array}{c}\text { Anaplasma } \\
\text { marginale/ovis }\end{array}$ & $\begin{array}{l}\text { Anaplasma } \\
+ \text { Theileria }\end{array}$ \\
\hline \multirow[t]{8}{*}{ Cattle } & 1. Andulo & $2 / 6(33)$ & $1 / 6(16)$ & $0 / 0(0)$ & $1 / 6(16)^{*}$ & $1 / 6(16)$ \\
\hline & 2. Kunje & $3 / 11(27)$ & $0 / 11(0)$ & $0 / 11(0)$ & $6 / 11(55)^{*}$ & 2/11 (18) \\
\hline & 3. Vila Graça & 3/19 (16) & $0 / 19(0)$ & 0/19 (0) & $10 / 19(53)^{*}$ & 2/19 (10) \\
\hline & 4. Kunhinga & $0 / 4(0)$ & $0 / 4(0)$ & $0 / 4(0)$ & $1 / 4(25)^{*}$ & $0 / 4(0)$ \\
\hline & 5. Kukema & $1 / 11(9)$ & $0 / 11(0)$ & $0 / 11(0)$ & $6 / 11(55)^{*}$ & 1/11 (9) \\
\hline & 6. Kuito & $0 / 4(0)$ & $0 / 4(0)$ & 0/4 (0) & $0 / 4(0)^{*}$ & $0 / 4(0)$ \\
\hline & 7. Lioema & $2 / 21$ & $0 / 21(0)$ & 0/21 (0) & $5 / 21(24)^{*}$ & $0 / 21(0)$ \\
\hline & Total & $11 / 76(14)$ & $1 / 76(1)$ & $0 / 76(0)$ & $29 / 76(38)$ & $6 / 76(8)$ \\
\hline \multirow[t]{3}{*}{ Goats } & 8. Catabola & 0/10 (0) & 0/10 (0) & $0 / 10(0)$ & $10 / 10(100)^{* * *}$ & $0 / 10(0)$ \\
\hline & 6. Kuito & $0 / 3(0)$ & $0 / 3(0)$ & $0 / 3(0)$ & $3 / 3(100)^{* *}$ & $0 / 3(0)$ \\
\hline & Total & $0 / 13(0)$ & $0 / 13(0)$ & $0 / 13(0)$ & 13/13 (100) & $0 / 13(0)$ \\
\hline
\end{tabular}

Numbers of farms correspond to those in Figure 1. ${ }^{*}$ A. marginale; ${ }^{* *}$ A. ovis.

Table II. - Prevalences of detected tick-transmitted pathogens. 
fully amplified from 29 bovine samples, 17 of them were sequenced, revealing 99-100\% similarity to an A. marginale sequences from Israel (AY786993), Italy (AY702922) and Zimbabwe (AY666011). A. marginale was detected at six out of seven farms, with prevalence ranging between $16 \%$ and $55 \%$. Sequencing of 12 amplified 18S rRNA fragments of Babesia/Theileria spp. and their following analysis employing MEGA software showed that one sample from Andulo displayed the highest similarity (99\%) with B. bigemina isolate originated from Kenya (accession number EF458200). All 11 remaining sequences revealed the highest similarity (99\%) with Theileria velifera strain from Tanzania (AF097993). The prevalence of Theileria sp. within particular herds ranged between $9 \%$ and $33 \%$, whereas samples of cattle from Kunhinga ( $\mathrm{n}=$ 4) and Kuito $(n=4)$ was PCR negative. In total, we detected six animals being infected by both $A$. marginale and T. velifera. We did not find any E. ruminantium positive sample. The results are summarized in Table II.

\section{DISCUSSION}

W e have diagnosed presence of four important tick-borne haemopathogens among only 89 sampled ruminants from eight farms (Fig. 1). The most prevalent blood parasites in our samples were A. ovis (100\%) in goats, and A. marginale $(38 \%)$ in cattle. Such a high prevalence could be explained by the easy transmission routes, when species of the genus Anaplasma can be transmitted by ticks, but mechanical transmission mediated by biting flies and vertical transmission can play a role as well (De Waal, 2000). Biological transmission is effected by more than 20 tick species (Kocan et al., 2004), when at least five competent vector ticks - namely Argas persicus, Rhipicephalus evertsi, R. sanguineus, R. simus and $R$. (Boophilus) decoloratus were recorded also from Angola (Walker et al., 2003). We do not expect that all goats in the region are Anaplasma-positive; however, the high prevalence of Anaplasma in goat herd in sub-Saharan Africa is not a surprise (e.g. BellSakyi et al., 2004).

Theilerioses, diseases caused by Apicomplexan parasites of the genus Theileria, belong to most important infectious diseases of ruminants in tropics and subtropics (Yusufmia et al., 2010). Among them, infection by different strains of $T$. parva causes the most severe theilerioses of cattle in Africa called East Coast fever (ECF), January disease, and Corridor disease. Whereas Rhipicephalus appendiculatus, the vector of ECF, is distributed in eastern Africa, $R$. duttoni and $R$. zambeziensis, both important vectors of Corridor disease, occur naturally also in Angola (Gomes et al., 1994; Walker et al., 2000, 2003). Moreover, earlier reports on clinical cases of Corridor disease in Angola are available (Sonenshine \& Mather, 1994). Nevertheless, we did not detect $T$. parva in our samples. It corresponds well with predicting distribution model for theileriosis in sub-Saharan Africa, where Angola remains "untouched" by ECF and by its tick vector $R$. appendiculatus (Olwoch et al., 2008). We found parasites of the genus Theileria widely distributed in Bié when sequencing attributes our isolates to T. velifera. This Theileria species is for long time considered to be non-pathogenic, and thus having low economic importance (Stoltsz, 1989; Bell-Sakyi et al., 2004). Nevertheless, Oura et al. (2004) stated that T. velifera, T. mutans, and T. taurotragi can cause in infected cattle ECF-like symptoms. Hence, our finding of $T$. velifera in five herds should not be ignored. Comparing to previous authors reporting mixed infections by different Theileria species in Rwanda, Uganda and South Africa (e.g. Bazarusanga et al., 2007; Oura et al., 2004; Yusufmia et al., 2010); we did not detect any animal possessing Theileria multi-infection.

$B$. bovis and B. bigemina are the causative agents of bovine babesiosis in sub-Saharan Africa, where their distribution ranges overlap into large scale (Bock et al., 2004). Among them, B. bigemina possess wider distribution, following the distribution of its main vector ticks $R$. (Boophilus) decoloratus and $R$. evertsi (Bock et al., 2004; Walker et al., 2003). We did not find $B$. bovis in our samples collection (data not shown, methodology according to AbouLaila et al., 2010). This situation can be caused by the lack of $R$. (Boophilus) microplus (the main vector of $B$. bovis) in Angola, as published by previous authors (e.g. Gomes et al., 1994; Walker et al., 2003). Our results correspond partially with outcomes of survey of 386 bovine sera collected in north-eastern South Africa by Mtshali et al. (2004). This team discovered $94 \%$ prevalence of $B$. bigemina, $87 \%$ prevalence of Anaplasma sp., and absence of $B$. bovis among studied animals. Despite the fact that we found only $1 \%$ prevalence of $B$. bigemina, due to the time-limited nature of parasitaemia leading to relatively smaller chance to detect Babesia by PCR method, this result should not be overlooked.

Ehrlichia ruminantium, the causative agent of heartwater disease, was not detected among our samples, despite the fact that Amblyomma pomposum and A. variegatum, both considered as competent heartwater vectors, were reported from Angola as a frequent tick species infesting cattle (Gomes et al., 1994; Walker \& Olwage, 1987). Regarding to the widespread occurrence and dynamics of spreading of heartwater disease intensified with possible vertical transmission (Deem et al., 1996), further study including serological analysis 
should be carried out to estimate the most imperilled areas by E. ruminantium in Angola.

Notably, despite the presence of four above mentioned blood parasites in Central Angola, all cattle and goats were without symptoms of disease. Asymptomatic development of infections could testify their endemic stability in the area. Such a state is defined as relationships between host, vector, and pathogen in environment, when clinical cases or symptoms of disease absent, or occur rarely (Bock et al., 2004). In spite of existence of vaccination programs in Angola, vast majority of farmers cannot support us with information about applied vaccines in their herds due to absence of reliable records. Hence, influence of acquired immune mechanisms (and innate immunity as well) in suppression of symptoms can also play a role. We found mixed infections of $A$. marginale and Theileria sp. in six animals. As confirmed by many previous authors, multi-infections in both wild and domestic ruminants of sub-Saharan Africa, are frequent (e.g. Awad et al., 2011; Figueroa et al., 1998; Oura et al., 2004; Pfitzer et al., 2011; Simuunza et al., 2011; Yusufmia et al., 2010). PCR methods give us short-term perspective in monitoring of epidemiological situation calling for employing serological methods. To clarify recent epidemiological threats and to reduce the economic losses in cattle farming in Angola, we suppose as basic the following measures - extensive epidemiological survey employing serology together with molecular genetic methods, monitoring of distribution of tick vectors, availability of vaccination programs, and tracking of animal transports.

\section{ACKNOWLEDGEMENTS}

Study was enabled by the project $279389 / 2009$-ČRA $\checkmark$ of the Czech Development Agency, implemented by the Institute of Tropics and Subtropics of the Czech University of Life Sciences Prague. Study was supported by the project "CEITEC - Central European Institute of Technology" (CZ.1.05/1.1.00/02.0068) from European Regional Development Fund. Lab works were supported by the Grant Agency of the Czech Republic (project No.524/09/0715). Michaela Kubelová is a Holder of Brno PhD Talent Financial Aid sponsored by Brno city municipality. We are indebted to all co-operative farmers for their assistance with sampling, and to Ministry of Agriculture and Rural Development, Republic of Angola, for necessary permits (No.03/ CSEA/GDG/SV/2009). Lesley Bell-Sakyi (University of Edinburgh, Scotland) and Gábor Földvári (Szent István University, Budapest, Hungary) provide us with Ehrlichia ruminantium and Anaplasma sp. positive controls, respectively.

\section{REFERENCES}

Aboulaila M., Yokoyama N. \& Igarashi I. Development and evaluation of a nested PCR based on spherical body protein 2 gene for the diagnosis of Babesia bovis infection. Veterinary Parasitology, 2010, 169, 45-50.

Awad H., Antunes S., Galindo R.C., do Rosário V.E., DE la Fuente J., Domingos A. \& El Hussein A.M. Prevalence and genetic diversity of Babesia and Anaplasma species in cattle in Sudan. Veterinary Parasitology, 2011, 181, $146-152$.

Bazarusanga T., Vercruysse J., Marcotty T. \& Geysen D. Epidemiological studies on theileriosis and the dynamics of Theileria parva infections in Rwanda. Veterinary Parasitology, 2007, 143, 214-221.

Bell-Saky L., Koney E.B.M., Dogbey O. \& Walker A.R. Incidence and prevalence of tick-borne haemoparasites in domestic ruminants in Ghana. Veterinary Parasitology, 2004, 124, 25-42.

Bock R., Jackson L., De Vos A. \& Jorgensen W. Babesiosis of cattle. Parasitology, 2004, 129, S247-\$269.

Bowles P.M., Molloy J.B., Blight G.W., Singh S. \& MabikaCHECHE L.G. Evaluation of a commercially available kit for detection of antibodies to Anaplasma marginale and $A$. centrale in cattle in Australia and Zimbabwe. Onderstepoort Journal of Veterinary Research, 2000, 67, 83-86.

DA Silveira J.A.G., Rabelo É.M.L. \& Ribeiro M.F.B. Detection of Theileria and Babesia in brown brocket deer (Mazama gouazoubira) and marsh deer (Blastocerus dichotomus) in the State of Minas Gerais, Brazil. Veterinary Parasitology, 2011, 177, 61-66.

Deem S.L., Norval R.A.I., Donachie P.L. \& Mahan S.M. Demonstration of vertical transmission of Cowdria ruminantium, the causative agent of heartwater from cows to their calves. Veterinary Parasitology, 1996, 61, 119-132.

DE la Fuente J., van den Bussche R. \& Kocan K.M. Molecular phylogeny and biogeography of North American isolates of Anaplasma marginale (Rickettsiaceae: Ehrlichieae). Veterinary Parasitology, 2001, 97, 65-76.

De WaAl D.T. Anaplasmosis control and diagnosis in South Africa. Annals of the New York Academy of Sciences, 2000, 916, 474-483.

Figueroa J.V., Alvarez J.A., Ramos J.A., Rojas E.E., Santiago C., Mosqueda J.J., Vega C.A. \& Buening G.M. Bovine babesiosis and anaplasmosis follow-up on cattle relocated in an endemic area for hemoparasitic diseases. Annals of the New York Academy of Sciences, 1998, 849, 1-10.

Gachohi J.M., Ngumi P.N., Kitala P.M. \& Skilton R.A. Estimating seroprevalence and variation to four tick-borne infections and determination of associated risk factors in cattle under traditional mixed farming system in Mbeere District, Kenya. Preventive Veterinary Medicine, 2010, 95 , 208-223.

Gomes A.F., Pombal JR. A.M. \& Venturi L. Observations on cattle ticks in Huila Province (Angola). Veterinary Parasitology, 1994, 51, 333-336.

Kocan K.M., de la Fuente J., Blouin E.F. \& Garcia-Garcia J.C. Anaplasma marginale (Rickettsiales: Anaplasmataceae): 
recent advances in defining host-pathogen adaptations of a tick-borne rickettsia. Parasitology, 2004, 129, S285S300.

Kocan K.M., de la Fuente J., Blouin E.F., Coetzee J.F. \& EwING S.A. The natural history of Anaplasma marginale. Veterinary Parasitology, 2010, 167, 95-107.

LaWrence J.A., Perry B.D. \& Williamson S.M. Corridor disease, in: Infectious diseases of livestock, $2^{\text {nd }}$ ed. Coetzer J.A.W. \& Tustin R.C. (eds), Oxford University Press, Cape Town, Southern Africa, 2004, 468-471.

Mahan S.M., Waghela S.D., McGuire T.C., Rurangirwa F.R., WASSINK L.A. \& BARBET A.F. A cloned DNA probe for Cowdria ruminantium hybridizes with eight heartwater strains and detects infected sheep. Journal of Clinical Microbiology, 1992, 30, 981-986.

Makala L.H., Mangani P., Fujisaki K. \& Nagasawa H. The current status of major tick borne diseases in Zambia. Veterinary Research, 2003, 34, 27-45.

Mtshali M.S., De WaAl D.T. \& Mbati P.A. A sero-epidemiological survey of blood parasites in cattle in the northeastern Free State, South Africa. Onderstepoort Journal of Veterinary Research, 2004, 71, 67-75.

Oкuthe O.S. \& Buyu G.E. Prevalence and incidence of tickborne diseases in smallholder farming systems in the western-Kenya highlands. Veterinary Parasitology, 2006, 141, 307-312.

Olwoch J.M., Reyers B., Engelbrecht F.A. \& Erasmus B.F.N. Climate change and the tick-borne disease, theileriosis (East Coast fever) in sub-Saharan Africa. Journal of Arid Environments, 2008, 72, 108-120.

Oura C.A.L., Bishop R.P., WAmpande E.M., Lubega G.W. \& TAiT A. Application of a reverse line blot assay to the study of haemoparasites in cattle in Uganda. International Journal of Parasitology, 2004, 34, 603-613.

Pfitzer S., Oosthuizen M.C., Bosman A.M., Vorster I. \& PENZHorn B.L. Tick-borne blood parasites in nyala (Tragelaphus angasii, Gray 1849) from Kwa-Zulu-Natal, South Africa. Veterinary Parasitology, 2011, 176, 126-131.

Provost A. \& Bezuidenhout J.D. The historical background and global importance of heartwater. Onderstepoort Journal of Veterinary Research, 1987, 54, 165-169.

Simuunza M., Weir W., Courcier E., Tait A. \& Shiels B. Epidemiological analysis of tick-borne diseases in Zambia. Veterinary Parasitology, 2011, 175, 331-342.

SonEnshine D.E. Biology of Ticks, vol. 2. Oxford University Press, NY, USA, 1993.

SONEnSHine D.E. \& MATHER T.N. Ecological dynamics of Tick-borne zoonoses. Oxford University Press, NY, USA, 1994.

STOLTSZ W.H. Theileriosis in South Africa: a brief review. Revue Scientifique et Technique de l'Office International des Épizooties, 1989, 8, 93-102.

Tamura K., Peterson D., Peterson N., Stecher G., Nei M. \& KUMAR S. MEGA5: molecular evolutionary genetics analysis using maximum likelihood, evolutionary distance, and maximum parsimony methods. Molecular Biology and Evolution, 2011, 28, 2731-2739.
UILENBERG G. International collaborative research: significance of tick-borne haemoparasitic diseases to world animal health. Veterinary Parasitology, 1995, 57, 19-41.

Van Amstel S.R., Guthrie A.J., Reyers F., Bertschinger H., Oberem P.T., Killeen V.M. \& Mathee O. The clinical pathology and pathophysiology of heartwater: a review. Onderstepoort Journal of Veterinary Research, 1987, 54, 287-290.

Walker A.R., Bouattour A., Camicas J.L., Estrada-Peña A., Horak I.G., Latif A.A., Pegram R.G. \& Preston P.M. Ticks of domestic animals in Africa. A guide to identification of species. Bioscience Reports, Edinburgh, Scotland, UK, 2003.

WALKER J.B. \& OlWAGE A. The tick vectors of Cowdria ruminantium (Ixodoidea, Ixodidae, Genus Amblyomma) and their distribution. Onderstepoort Journal of Veterinary Research, 1987, 54, 353-379.

Walker J.B., KeIrans J.E. \& HoraK I.G. The genus Rhipicephalus (Acari, Ixodidae). A guide to the brown Ticks of the World. Cambridge University Press, Cambridge, UK, 2000 .

Yusufmia S.B.A.S., Collins N.E., Nkuna R., Troskie M., van Den Bossche P. \& Penzhorn B.L. Occurence of Theileria parva and other haemoprotozoa in cattle at the edge of Hluhluwe-iMfolozi Park, KwaZulu-Natal, South Africa. Journal of South African Veterinary Association, 2010, $81,45-49$.

Received on February $24^{\text {th }}, 2012$ Accepted on June $12^{\text {th }}, 2012$ 